821.111.09 Burns R.

https://doi.org/10.18485/bells.2019.11.12

\author{
Natalia Kaloh Vid* \\ University of Maribor \\ Faculty of Arts, Department for Translation Studies \\ Maribor, Slovenia
}

\title{
ROLE OF PARATEXTS IN MEDIATING IDEOLOGICALLY ADAPTED TRANSLATIONS IN THE SOVIET UNION: THE CASE OF ROBERT BURNS
}

\begin{abstract}
The main aim of the current research is to demonstrate how the communist regime established in the Soviet Union after the October revolution and characterized by a centralized state control over all social discourses, including literature, functioned in practice. The paper focuses on reviews, prefaces and articles that accompanied Soviet translations of Robert Burns, one of the most famous and beloved foreign poets in the Soviet Union, their impact on readers and relevance for supporting the official ideology. Due to the variety of materials on Burns published by the Soviet press, the focus of the article is on those works that appeared in the 1930s-1950s when the official image of Burns was initially promoted. Similarity among paratextual devices used by the authorities in the 1930-50s to promote an ideologically favourable image of Burns included above all adaptations and even fabrications of the poet's biography and ideologically favourable interpretations of Burns's poems. The role of manipulative paratextual devices is significant, considering that the target readers' access to the world of foreign culture was limited on the whole to literary translations.
\end{abstract}

Key words: paratexts, ideology, Robert Burns, Soviet, translations

E-mail address: natalia.vid@siol.net 


\section{Introduction}

The totalitarian regime established in the Soviet Union shortly after the October Revolution of 1917 was characterized by centralized state control with power over all aspects of private and public life, including the economy, politics and the arts. From the first day of their rule, the Bolsheviks saw the free word as a moral threat to their power. New ideological propaganda dictated harsh restraints on literary production, aiming to purge Soviet society of all expressions regarded as destructive to the new order. All literature published in the USSR had to meet specific state-derived standards, as the political situation created a highly controlled atmosphere with the edicts of socialist realism. Censorship became a primary mechanism of control; henceforth, literature and translations lost some of their public identification with civil society and gained a formal place in the official culture of the Soviet era. Following the new propagandistic role of literature, Soviet writers were expected to advocate the six main virtues of the official communist ideology: collectivism, discipline, love of work, patriotism, proletarian internationalism and atheism (O'Dell 1978: 16-18). Soviet censorship severely suppressed any criticism of the current regime which proved to be the longest lasting and the most comprehensive system of state censorship in the twentieth century.

Bearing in mind the significance of literature for the promotion of socialist values, the Soviet authorities considered literary translations as ideological tools, inevitably influenced by an institution of censorship and strict centralization. According to Goriaeva, "political censorship had one more, perfect and unmistakable, method, i.e. ideologically corrected translation /.../ which enabled a falsified projection of a development of literature always interpreted according to Marxian-Lenian ideology." (Goriaeva 2009: 363) Similarly, Witt claims that,

To the field of translation studies the Soviet case generally provides rich material for the discussion of topical matters linked to issues of 'translation and power,' 'translation and ideology,' 'translation and empire,' etc. In particular, Soviet practices developed within the field of indirect translation, producing such paradoxical entities as "original interlinear trots" and "secondary originals," supplies new perspectives on such key concepts as source language, target language, authenticity, and translational agency. (Witt 2001: 168) 
Consequently, translations, though flowering in the Soviet period and celebrated as an important vehicle in the service of the people, were also subjected to censorship as the essence of the Soviet state's ideological strategy consisting of forcing the public to read what was officially allowed, while isolating people from any other sources of information outside state control. ${ }^{1}$ Translators were expected to promote ideological values by changing and adapting the source texts according to the newly established ideological demands.

Though Soviet readers were offered limited access to literature, especially to foreign literature, the authorities also used various paratextual devices, including reviews, criticism, interviews and prefaces, which played a significant role in mediating, guiding and controlling readers' engagement and interpretation. Unfortunately, the authority of subordinated, usually non-professional, commentators to discuss literature was inherent in the limitless executive power of the Soviet system. Paratexts attached to translations were supposed to explain the merits or defects of various authors' works to the readers. As most of them were unfamiliar with the real political and cultural situation in foreign countries, there was always the possibility of a potentially problematic or ambiguous interpretation.

The purpose of this paper is to demonstrate how this stage of control functioned in practice by analyzing reviews and prefaces that accompanied translations of Robert Burns, one of the most famous and beloved foreign poets in the Soviet Union, their impact on readers and their relevance for supporting the official ideology. Due to the variety of materials on Burns published by the Soviet press, the focus of the article is on those works that appeared in the 1930s-1950s when the official image of Burns was initially promoted. Paratexts, which appeared later, followed the established canon closely.

1 Russia's long history of censorship has been well documented in numerous publications both by Russian and Western experts. However, the actual records of the vast number of books and newspapers that were subjected to strict censorship in Imperial Russia and the USSR are still only accessible in special collections, the Russian language manual catalogue card archive and printed lists deposited in the National Library of Russia in St. Petersburg (pre-revolution period) and the Russian State Library in Moscow (the USSR period). 


\section{Censorship and control of the publishing process in the Soviet Union: Glavlit}

Since, in the Soviet Union, censorship was based on reasons of power, and used by governments to force the public to read what was prescribed for it, people were cut off from any other sources of information outside state control (Stelmakh 2001: 145). According to Blyum, this method of keeping a group of people, or the whole nation, ignorant by isolating them from the outside world, has historically been the most successful way of maintaining totalitarian government (2003: 3). In the Soviet Union, official censorship on various levels became a necessary agent for the maintenance of the Soviet State and the Communist Party, regulated by the authorities and organized as a complex, though efficient mechanism (Lauk 1999: 19). The highest decision-making level was represented by the Secretary General of the Communist Party, the Politbureau (central governing body of the Communist Party), the Agitation and Propaganda Department of the Central Committee in Moscow, and the KGB structures, including the Fifth Department, which determined most of the topics and issues to be banned in publications.

The publishing process in the Soviet Union, monopolized by the state, was also subjected to censorship and strictly controlled. Thus in 1919 all publishing houses were united and subordinated to the major publishing body initially called Gosizdat (State Publishing House) and established in order to create a single government organization for printing. Gosizdat acted as the Central Committee's main book publisher and was afforded special privileges, including large state subsidies and freedom from external ideological censorship. In August 1930, a new, centralized publishing conglomerate, the Association of State Book and Magazine Publishing Houses known as OGIZ, was established. Gosizdat remained the core of OGIZ. ${ }^{2}$

In 1922, in addition to Gosizdat, the official censorship office, ${ }^{3}$ named Glavlit (General Directorate for the Protection of State Secrets in the Press

2 Even after this time, it was not uncommon for Soviet sources to use the term gosizdat to describe the Russian Republic's main publishing operation, regardless of its official name at the time.

3 Publications of the Communist Party, Gosizdat, the All-Russian Central Executive Committee, and scholarly writings of the Academy of Science were exempt from censorship. 
under the Council of Ministers of the USSR) was established to regulate the Soviet book market. Editors and censors employed at Glavlit formed a united filter against authors, received instructions directly from the Party and edited texts, including translations, to serve ideological purposes. The editors-in-chief of periodical publications such as Innostrannaya literatura (Foreign literature) and all publishers were accountable to controls led by Glavlit and were obliged to provide censors with the plans for texts to be published over the following months (Lauk 1999: 22). Glavlit's primary function was to carry out preliminary inspection of nearly all manuscripts and printed material (including translations) as well as photographs, drawings, and maps intended for publication and distribution, and radio programmes (Ermolaev 1997: 3). It had a right to prevent the publication and distribution of any piece of writing, above all, those which:

(1) contained propaganda against the Soviet regime, the Soviet Union, particular political bodies and figures (a censor had to be aware of the political platform of an author and his/her loyalty towards the Soviet Union and Communist Party);

(2) divulged military secrets;

(3) stirred up public opinion through false information;

(4) aroused nationalist and religious fanaticism, propaganda of fascism, violence or terror;

(5) were pornographic (Ermolaev 1997: 3-4).

Generally speaking, everything that did not fall under Socialist Realism was forbidden (Richmond and Solodin 1997: 585). Printing facilities and the distribution network were also subordinated to Glavlit, which was technically part of the Commissariat of Enlightenment, though in practice it answered directly to the Communist Party's Central Committee, which appointed its board of directors, reviewed editorial appointments, and monitored its work. Glavlit was also responsible for purchasing and censorship of foreign literature, registration or shutting down of new publishing houses, regulating print runs, approving publishers and editors, and compiling lists of politically harmful literature that had to be removed from the book market (Clark and Dobrenko 1999: 122).

Thus, in 1922 the Department of Russian Literature denied registration to sixteen publishing houses and twelve magazines in Moscow and Petrograd (Ermolaev 1997: 5).

According to Blyum, Glavlit occupied the middle place in the fivelevel pyramid of control. Below it were filters provided by authors and 
editors, above it the directives of the police and the Party, which had to be carried out rigorously (Blyum 2003: 7-8). The product of this system was supposed to be a "pure", ideologically transparent text that conformed in every respect to the Party's ideological aims and demands. Above Glavlit stood the figure of the Party General Secretary, the head of the Soviet Union, who presented the final level and whose verdict was beyond further discussion (Blyum 2003: 8). Renamed several times, Glavlit functioned until the 1990s.

In such an environment, "reading between the lines" and searching for hidden meaning became crucial for the writing and reading process. In order to justify their existence and to demonstrate their cautiousness to prevent any suspicious text from being published, editors scrupulously examined every line. According to Vladimir Solodin, chief Soviet censor, editors' demands of any kind (additions, comments, erasure) had to be strictly followed. In his own words, he was trusted with tremendous power over the fate of books and the fate of authors, and the writers feared him (Stelmakh 2001: 583). In the case of political or economic publications, it was easier to separate a harmful publication from a "good" one, taking into account only ideological reasons. In the case of fiction, it was more difficult for censors to judge.

The authorities also strictly centralized, censored and controlled the publication and distribution of translations of foreign literature, as a part of the publishing system. Translations of foreign materials had to pass a special censorship control at the Foreign Literature Committee (Committee for the purchase and distribution of foreign literature in the Soviet Union) subordinated to Glavlit and were not permitted either in small local libraries or even in private book collections. ${ }^{4}$ The Ministry of Culture had the right to coordinate publication of translations by the Publishing House of Foreign Literature (Izdatelstvo inostrannoi literatury), set up in 1946 to publish Russian translations of foreign literature and also books on social and scientific topics. The publishing house was linked to the All-Union State Library of Foreign Literature, founded in 1948. It selected material from the library and purchased a large number of foreign books and journals from abroad, which were always censored by Glavlit (Gorokhoff 1959: 156-157).

There were one or two notable exceptions such as the Library of Foreign Languages in Moscow. 
The choice of texts was strictly regulated. Translators had to obtain at least two recommendations for their translation from scholarly institutions or specialists and secure the agreement of the appropriate chief editorial office in the State Committee for Publishing. Only after this could they submit details of the work for "coordination" to the State Committee or (in the case of scientific and technical works) to the State Scientific and Technical Library (Sherry 2012: 15).

The selection of translators, and of authors to write any notes or introduction, had to be approved by a senior editor or the head of an editorial office. Working with foreign publications the censors had to be very knowledgeable and to possess some special abilities. They were tasked "to protect the minds of the Soviet people from the harmful influence and infection of the West" (Sinitsyna 1999: 36).

It was difficult, in most cases even impossible, to get access to foreign literature in the language of the original. Bookstores, small local libraries and private collections could not purchase literature published in Western countries. Professors and students of foreign languages at the state universities could get access to the original works, but even in this case, the lists of permitted works were controlled. Censors strictly controlled foreign books and periodicals, which reached the famous Library for Foreign Languages, ${ }^{5}$ a unique example of this kind in the Soviet Union, or the Academy of Science or the Russian State Library. Politically incorrect books were forbidden. A triangle meant that the publication could be stored in the main stacks and was accessible to the public (1999: 37). Inootdel (The Department for Foreign Literature) held a catalogue of books and periodicals that had already undergone censorship with notes on the censors' decision. ${ }^{6}$ The censor checked this catalogue before reading a given item, and noted the previous judgment in his or her report (Goriaeva 2009: 358). This catalogue helped the censors to define the items accessible to the public.

5 According to Sinitsyna, The Library for Foreign Languages received books only twice a year and each one bore a special mark on the title page with the personal number of the censor.

6 By the end of the 1980s, this card catalogue held more than one million records but was destroyed upon the liquidation of Glavlit owing to a lack of computers onto which the information could be recorded and the absence of a suitable archive into which it could be placed. However, what remains of the Glavlit archive is currently held by the State Archive of the Russian Federation (GA RF) but in its original form it would undoubtedly have held a huge amount of useful information on the current topic. 
A hexagon meant that the publication should be kept in the special stacks and access to it should be strictly limited. The publication could have two or even three hexagons on the title page, indicating that it might be ideologically harmful (Sinitsyna 1999: 36-37) and could be kept only in what was called "the restricted access collection", in special sections known as spetskhran (an abbreviation for a Special Storage Section) regulated by Glavlit. A huge number of texts were placed in spetskhrany. Thus, the Lenin Library held more than one million items (Goriaeva 2009: 358). Access to these spetskhrany was limited to those in possession of special permits, such as specialist researchers and translators, and was on a referenceonly basis. Thus, it was only when a translator got a permission for and a contract to translate a foreign book, that a working copy of the text from the spetskhran could be made. The "fate" of a foreign book depended on a number of factors, but above all, "the censor had to be aware of the political platform of an author and his [sic] loyalty towards the Soviet Union and Communist Party" (Sinitsyna 1999: 38).

\section{Mediation of Robert Burns in translation: the role of reviews and prefaces}

Clearly, we cannot talk about a free, market-oriented selection of translated literature in the Soviet Union, since the beginnings in the 1930s, the primary assessment criteria for Western literature became its usefulness, appropriateness or at least non-harmfulness to the Soviet regime. ${ }^{7}$ The choice of translated works was politically motivated, while numerous censors and editors ensured that the texts were suitable for Soviet consumption. Once the text was selected for translation and distribution, the process of ideological framing by means of accompanying "educative" paratextual devices started.

Similar to translations of other Western authors, translations of Robert Burns, though highly popular, were not exempt from ideological interpretation. In the 1930s when the pressure on literature to sanction the official image of Soviet society increased, translations of Robert Burns 7 It should be noted that in the Soviet ideological environment, the term "usefulness" far
exceeded any poetic qualities. 
from the nineteenth century ${ }^{8}$ could no longer fulfil the new aesthetic function of literature as a vehicle for ideological propaganda. Translations of Burns's poetry made in the Soviet Union would have to follow the main ideological doctrines and include such features as a positive revolutionary hero, heroic acts, optimism, references to communist slogans, omissions of religious and erotic connotations and so forth. Following the official ideological demands and striving to satisfy vigorous censors, Burns's only official Soviet translator, Samuil Marshak, ${ }^{9}$ significantly intervened with the originals by deliberate omission, substitution and modification. ${ }^{10}$

Once Marshak began translating Burns's poetry, the process of the poet's canonization started with a number of reviews and articles that accompanied Marshak's translations. Brian Kassof notes, in relation to the early editions of the Bolshaia sovetskaia entsiklopediia (Great Soviet Encyclopedia) that "the Bolsheviks were intense readers of signs of all types, including paratextual cues" (Kassof 2009: 59), and the use of paratexts in the Stalin and post-Stalin era confirmed this statement. According to Safiullina, "canonization means a set of obligatory norms for creativity" (2012: 559) and canonization of selected foreign writers in the 1930s formed an important part of official policy regarding translated literature. In contrast to the canonizing process in Western art, a canon in the Soviet Union was based on the official policy of Social Realism and had strongly normative functions (Ibid., 559). In the canonizing process, writers' biographies were often adapted and used as a means of ideological propaganda. Safiullina also states that canonization was not a result of "any debate" but the leading role in the canonization process of the 1930s1940s belonged to Stalin, who personally decided which Western authors could be translated and mediated in the Soviet Union (Ibid., 559).

8 In the nineteenth century, most of Burns's love and nature lyrics were translated, but his satires, democratic lyrics, which contained appeals to the sentiments of freedom and citizenship, patriotic songs and ironic epigrams remained unknown to Soviet readers.

9 However, the undeniable literary quality of Marshak's translations raises the question of the potential to combine literary value with purely ideological formations.

10 Ideological changes made by Marshak are thoroughly analyzed in Kaloh Vid's researches Ideological translations of Robert Burns' poetry in Russia and in the Soviet Union (Maribor: Zora, 2011) and "The reception of Robert Burns in Russia" In The reception of Robert Burns in Europe, ed. Murray Pittock. (Bloomsbury: London, New Delhi, New York, Sidney, 2014). 
The process of "Burnization" started with a short review published in 1938 in Literaturnaya gazeta (Literary newspaper) by one of the most famous Soviet poets, V. Lebedev-Kumach, who proclaimed Burns's poetry useful for a new socialist culture by stating that "we may learn a lot from Burns, as he made national poetry his own and his own poetry national." (1938: 5) To emphasize the necessity for new translations, Lebedev-Kumach mentioned that "we know little about a famous Scottish bard" (Ibid., 6), ignoring the fact that Burns was already translated in the nineteenth and at the beginning of the twentieth century, when Tatiana ShchepkinaKupernik, one of the most prominent Russian translators of the time, translated a number of poems. Lebedev-Kumach estimated ShchepkinaKupernik's translations to be "poor and unable to transfer the flavour of the originals." (Ibid., 8) In other words, previous translations were not ideologically adapted. In what follows Lebedev-Kumach stated that the Soviet reader needed new translations and the work had already begun, "I am certain that all of you who love poetry will be happy to learn that a great master, Samuil Marshak, has already started translating Burns." (Ibid., 15) Lebedev-Kumachev's text comprises regular features of Soviet reviews, which usually appeared in the press before the translations were published. Firstly, a reviewer intensified the "usefulness" of the author for a new, progressive, socialist art; secondly, he/she stated that previous translations were not good, faithful, useful or appropriate, and finally informed the readers that new translations were coming.

Mikhail Gutner's propagandistic article about Burns's life entitled "Robert Burns", the first biographical note about Burns published in the Soviet Union, appeared in the same issue of Literaturnaya gazeta. As all great Western writers were supposed to emerge from the most revolutionary class, the working class, first of all Gutner drew the readers' attention to the fact that Burns was born into the poor family of a common farmer, which had nothing to do with the aristocratic circles strongly criticized in Soviet literature. Gutner's emphasis on Burns's roots is not accidental, as one of the most important aims of paratextual material was to present prominent Western authors as supporters of the communist doctrine and to assess them by applying the same criterion as was used for Soviet writers. Among other issues, Soviet critics advocated the use of biographies as a means of ideological adaptation. In this process, the background was one of the most important issues aimed at establishing the authors' "proletarian spirit," regardless of their poetic talent. Thus, it was of special importance 
to interpret not only Burns's poetry but also his biography according to ideologically acceptable standards, which meant, above all, to intensify his "proletarian" background.

The importance of the term "proletarian" should be clarified here. In 1934, the First All-Union Congress of Soviet Writers placed on record that the future belonged to the international revolutionary literature, for it was linked up with the struggle of the working class for the liberation of all mankind. ${ }^{11}$ Thus, in the Soviet Union, the proletarian (almost the synonym of lower class) family origin was considered not merely "trustworthy" but absolutely necessary for acquiring a job, getting permission to travel abroad and even simply avoiding imprisonment. In a similar manner, most foreign writers translated in the Soviet Union either belonged to the working class, or at least sympathized with it (e.g. London, Dreiser, Dickens, etc.).

Following this pattern, in a pathetic description of Burns's early life, Gutner intensified the poet's origins. Thus, Burns's father "the poorest of Scottish farmers" was fighting "the ghost of poverty his entire life" and finally died "broken in this unequal fight."(Gutner 1938: 5) As Burns needed to help his father, Gutner stated that "the young boy had to work as hard as slaves on ships" (Ibid., 5), using an overly expressive vocabulary to stress the conditions of Burns's early years and to demonstrate how "proletarian" the poet's family was.

Apart from this, Burns's poetry was once again pronounced "useful" (Ibid., 5) for a new socialist culture, while the poetic qualities of his work were ignored. The critic also reminded Soviet readers that the main reasons Burns could not assert himself successfully as a poet in England were his sympathies for the French Revolution, or as Gutner states "revolutionary passion and aggressive humanist pathos" (Ibid., 7), which demonstrated Burns's open protest against the English aristocrats.

To stress Burns's connection with the poor and with revolutionary circles, Gutner permitted himself a few invented "facts" in his biography. For example, he asserted that Burns first gave his poems with revolutionary contexts to his countrymen, who were impressed and dismayed by his brevity. In fact, no dates exist that confirm that Burns really did give his poems to his countrymen. Moreover, ignoring the fact that Burns's first

11 "Resolution on the Report of Maxim Gorky, the co-Reports of S. Y. Marshak and the Report on the Literature of the National Republics. (Adopted at the Morning Session on August 23, 1934)," Marxists Internet Archive 2004, accessed June 15, 2014. http://www.marxists.org/subject/art/lit_crit/sovietwritercongress/resolutions.htm 
poems were devoted to his sweetheart ("Handsome Nell"), Gutner made another interesting addition: that Burns started his poetic career with satires on the church and priests. As Soviet ideology rejected any kind of religion and church as an independent institution, it was important for Soviet critics to present Burns as anti-Christian. Gunter observed that Burns considered priests "brothers of bourgeois exploiters." (Ibid., 7-8) As an example of an anti-Christian poem, he mentioned "Holly Willie's Prayer", a satirical poem free of any ideological grounds (Kaloh Vid 2014: 161). Another Burns poem "Jolly Beggars", a cheerful cantata, was taken to illustrate the poet's revolutionary spirit and seen as an "appeal to the national revolt." (Gutner 1938: 7) The beggars in the poem were also supposed to be happy primarily because they were free "of the burden of property" (Ibid., 7).

While briefly mentioning Burns's numerous love affairs, which "contradicted written puritanistic morality" (Ibid., 8), and caused the poet numerous troubles, Gutner devoted a whole paragraph to Burns's political views, which were patriotic and democratically oriented, though sometimes "unstable" and "ambiguous." (Ibid., 9) Gutner found Burns's sympathy towards the royal dynasty of Stuarts problematic, but it should be noted that, unlike the paratextual materials accompanying other Western authors, those related to Burns almost never pointed out potential "failings" of his poetry. Thus, Gutner explained and justified the poet's sympathy for the royal dynasty by stating that some "unfortunate poems on this subject" (Ibid., 9) should be interpreted as the only forms in which Burns was able to express his democratic patriotism. Jacobitism in Burns's poetry was "not real but imaginary, created under circumstances" (Ibid., 9) as otherwise Burns hated royalty, aristocracy and the bourgeoisie. The critic somehow forgot to mention the fact that the poet had many friends who belonged to the upper class and introduced a strict delineation between Burns as a representative of the working class and his "enemies" exemplified by the bourgeois, Jacobites, aristocrats, and priests.

As one of the principal Soviet ideas espoused in literature and other forms of art was that of individual sacrifice for the common good, willingness to become integrated into the community and a wish to subjugate personal welfare to collective interests, Gutner concluded by stating that "Burns's poetry was hostile towards individualism and contrary to other romantic poets, he believed in the nation and its spirit." (Ibid., 10) It also seemed necessary to mention that the poet had already been "approved" by one of 
the founders of the communist ideology, Karl Marx, who "enjoyed reading Burns's poetry to his daughters." (Ibid., 10)

Clearly, Gutner presented Burns as ideologically correct and made an extensive and liberal use of ideologemes and lexical items that contained reference to ideology or cultural norms in order to insert his evaluation of Burns as a man and a poet.

Hence, Burns's new role in Soviet translated literature required further induction and transformations. In 1939, the first translations of Burns by Samuil Marshak were published in Molodaya gvardiya (a literary newspaper), accompanied by Alexander Anikst's article "Robert Burns". Similarly to Gutner's, this paratext made heavy use of ideologically marked statements to describe Burns's life, implicitly framing it in Soviet terms and imposing the "correct" interpretation. In the introduction, Anikst once again stressed Burns's origins. The fact that Burns was a poor farmer's son was presented as one of the key factors in the development of the poet's "democratic spirit."(Anikst 1939: 107) Further establishing the role of Burns as a poet of revolution, Anikst emphasized his sympathy with the French revolution. It is true that Burns admired the courage of French revolutionists in the poem "The Tree of Liberty", however, the statement that his entire poetical heritage was denoted by the French revolution is a huge exaggeration. The critic also mentioned the Scottish circle of those who approved and supported French revolutionaries, supposedly led by Burns (again a completely fabricated claim). It is not surprising that in what follows, Burns was called "a poet of revolutionary democracy who fought for lower classes." (Ibid., 107)

Placing Burns among the most progressive strugglers for democratic rights, Anikst emphasized his importance in the development of romantic English literature - which is partly true. However, his statement that Burns should be considered one of a few truly progressive romantic English poets seems exaggerated. The term "progressive Romantic poet" (Ibid., 108) is also problematic, as Anikst did not bother to explain what he actually meant by this.

As Western authors translated in the Soviet Union were often presented as victims of a capitalist system, shifting the focus of the analysis from Burns's poetic achievements to his social status, Anikst presented Burns as a victim of the upper classes. In an attempt to add ideological cohesion to this part of Burns's biography, Anikst stated that the main reasons for the poet's alcohol problems were poverty and the suffering of the poor, which 
forced him to start drinking. As Burns saw himself as helpless and unable to change anything or to improve the life of the lower classes, the "ugly reality of bourgeoisie society destroyed the life of a genius, and was responsible for his early death." (Ibid., 108) Grief and society's cruelty were the main reasons for the poet's early death, but as a canonized poet he could not be presented as a complete pessimist and sufferer, Anikst stressed the cheerful nature that helped Burns to cope with all obstacles with a smile on his face. The last "strike" was the statement that Burns was successfully married (only once), adored his wife, and could be praised for his exemplary family life. (Ibid., 108) For obvious reasons, Anikst forgot to mention the fact that Burns married Jean Armour when they already had several illegitimate children and had numerous mistresses before marriage.

The canonization of Burns was further fostered by constant repetition and consolidation of the same pattern. When the first collection of Marshak's translations was published in 1947, it was accompanied by a preface by M. Morozov. While continuing the pattern already established by Anikst and Gutner, Morozov introduced a new ideologeme, the image of enemies, "anti-revolutionists", who "continue to hate Burns and do everything they can to diminish his importance." (Morozov 1947: iii-viii) It is not surprising that throughout Soviet history one of the ideological means of unifying the people was the creation of the image of the enemy who was presumably responsible for all misfortunes. Implying a familiar ideologeme, Morozov presented Burns as a victim "haunted by his enemies who spread lies about his life." (Ibid., iv) Presumably, those fabricated claims about Burns were later used by Scottish anti-revolutionary movements to slander the image of Burns as a progressive revolutionary poet. Thus by drawing upon a recognizable metaphor of the enemy, Morozov established the Soviet Union as the only country that not only understood and appreciated Burns but was also responsible for protecting his good name against the "enemies".

Morozov's preface also differs from the others in structure. Instead of emphasizing Burns' origins and the poor life conditions of his family, Morozov stated that many Scots were forced to leave Scotland because of impossible life conditions in the country with no freedom and democracy (Ibid., iii). Clichés focused on the poor treatment of workers and economic problems in Western countries were often to be found in the Soviet discourse and served to confirm Soviet criticism of the West in contrast to the prosperity of the proletarian class in the Soviet Union. In Morozov's perception, many of those who left Scotland carried the image of Burns 
in their hearts and continued reading his poetry in exile. He mentions "shepherds from Australia and miners from California" (Ibid., iii), signifying that only common workers could appreciate Burns's poetry.

Morozov's interpretation of Burns's poems leaves no doubts about the critic's intention to continue a well-established interpretation of Burns as a revolutionist and a democrat. The main problem is that, similar to Gutner and Anikst, Morozov discovered revolutionary sub-tones in poems free of any such context. Thus, the poem "John Barleycorn", which depicts the process of making whiskey, a national Scottish drink, was supposed to express the "unconquered strength of people." (Ibid., vi) While in the original, John Barleycorn represents the crop of barley harvested in autumn and symbolizes whiskey, in Morozov's perception the metaphorical John is set as one of the revolutionists who encouraged people to start a revolt against capitalist oppression. Following the pattern established by Gutner, Morozov draws the link between Burns and the French revolution by stating that "Jolly Beggars", the poem mentioned above, clearly expressed "people's rage similar to that which destroyed the Bastille." (Ibid., vii) The poem "Scots Wha Hae", which comprised an appeal of the Scottish king, Robert the Bruce, to fight for Scotland at the famous battle of Bannockburn in 1314 was interpreted "not merely as a historical poem but above all as an appeal to Scots to fight against English aristocrats here and now." (Ibid., vii)

Those poems by Burns which could not be interpreted as humanistic, democratic or revolutionary were criticized. Thus, Morozov briefly mentions that Burns's early poems did not sufficiently reflect the poet's subsequent revolutionary ideas. As an example, he mentions "Cotter's Saturday Night", an idyllic, pastoral "empty and completely useless" poem. Hence, Morozov immediately finds an "excuse" for Burns, as it was one of his first poems written in the years when "the poet's revolutionary mentality was not yet fully established." (Ibid., vi) In the end, Morozov states that the Soviet translations of Burns were the best in the world, far from "primitive attempts by bourgeoisie translators to transfer Burns' spirit" (Ibid., viii).

The process of Burns's canonization continued in the 1950s when the Soviet translator Rait-Kovaleva, published an article "Robert Burns about himself". Following the ideas about misinterpretation of Burns by Western critics, she emphasized in the introduction that little was known about Burns' life, as biographies written in England and Scotland degraded the image of the national poet and never succeeded in revealing the democratic, revolutionary essence of his poetry. According to Rait- 
Kovaleva, English biographers of Burns attempted to present him as an alcoholic and uneducated peasant poet in order to lower his significance for world literature. All previous biographies ${ }^{12}$ were proclaimed "bourgeois perversions" that did not reveal the democratic and revolutionary essence of Burns' poetry (Rait-Kovaleva 1959: 187). Rait-Kovaleva carefully used Burns's letters and quotations from his poems to illustrate a concept of his life and poetry, following the already established patterns (Kaloh Vid 2014: 162).

Among other highly propagandistic articles about Burns published in the 1950s were also Gerasimov's article "Scottish Poet", in which Gerasimov claimed that the Soviet Union was the only country in which Burns was properly understood, honoured and loved (Gerasimov, 1959: 20), Samarin's "Robert Burns", Rogov's "The Singer of Freedom", and Elistratova's "Robert Burns". All of them emphasized similar, carefully adapted, aspects of Burns's life and poetry: proletarian origin, patriotism, revolutionary spirit, and neglect of his revolutionary poetic importance by Western, especially British, critics.

\section{Conclusion}

Considering the enormous power of censorship, translations made in the Soviet Union represented products of collective, enforced cooperation between translator and the state. As an important part of this process, institutionalization of paratextual devices, including reviews, prefaces and critical articles, inevitably effected the translations' mediation and interpretation. The main purpose of paratextual devices was not merely to recommend the text to the attention of readers but to recast a book as something it was often not and to put an ideological spin, more or less imperative, on a suitable candidate. As a result, the reader was offered a clear pattern, repeated in various forms, which left little space for any other interpretation but the official one.

The discussion above outlined the ways in which the textual apparatus employed by the Soviet state promoted the translations of Robert Burns to readers, though we can only guess to what degree ideologically derived

12 There were two adapted biographies of Burns published in the Soviet Union: Elena Elistratova, Robert Berns (Moscow: Gosizdat, 1957) and Rait-Kovaleva, Robert Berns (Moscow: Molodaia gvardia,1965). 
reviews and prefaces influenced the readers' perception since almost no material on the readers' authentic response is available. Hence, we assume that ideological influence may be especially strong and effective in paratextual devices that accompany literary translations because they represent one of the most common and sometimes the only way of connecting and mutually informing divergent cultures.

Similar paratextual devices used by the authorities in the 1930-50s to promote Burns illustrate that unfortunately, within the totalitarian ideology, literary criticism became one of the means of manipulating reality and forcing it to conform to the propagandistically correct ideas. Indeed, whereas all ideologies tend to present the logic of an idea as scientific, totalitarian ideology was unique in the sense that it ignored reality (Kaloh Vid 2014: 160).

The role of manipulative paratextual devices was important because, in a country behind the iron curtain, literary translations offered the target Soviet readers almost their only opportunity to become familiar with the world of foreign culture. Totalitarianism not only isolated people from the outside world, it enclosed them in an artificial universe in which they had no standards of comparison. Thus, paratextual devices that accompanied translations were supposed to construct and lead target readers' conceptions and presumptions not only about a particular author but also about the foreign cultural environment in general, which could be positive or negative, depending on the ideological purpose.

\section{References}

Anikst, A. (1939). Robert Burns. Molodaya gvardiya, 4, 107-108.

Blyum, A. (2003). A Self-Administered Poison. The System and Functions of Soviet Censorship. University of Oxford: Oxford.

Clark K. and E. Dobrenko (eds.) (1999). Soviet Culture and Power: A History in Documents, 1917-1953, trans. Marian Schwartz. New Haven: Yale University Press.

Elistratova, E. (1959). Роберт Бернс. Literaturnaia gazety, 24, 3-10.

Ermolaev, N. (1997). Censorship in Soviet Literature 1917-1991. Rowman \& Littlefiled: USA.

Gerasimov, G. (1959). Shotlandskii poet. Novoe vremia, 8, 16-23.

Goriaeva, T. (2009). Politicheskaia tsenzura v SSSR 1917-1991. Moskva: Rossiskaia politicheskaia entsiklopedia. 
Gorokhoff, B. (1959). Publishing in the U.S.S.R. Bloomington: Indiana University Press.

Gutner M. (1938). Robert Burns. Literaturnaya gazeta, 45, 5-10.

Kaloh Vid, N. (2014). The Reception of Robert Burns in Russia. In: M. Pittock (ed.), The Reception of Robert Burns in Europe, Bloomsbury: London, New Delhi, New York, Sidney, 155-179.

Kassof, B. (2009). A Book of Socialism: Stalinist Culture and the First Edition of the Bol'shaia Sovetskaia Entsiklopediia. Kritika: Explorations in Russian and Eurasian History, 6, 55 -95.

Lauk, E. (1999). Practice of Soviet Censorship in the Press: The Case of Estonia. Nordicom Information 21(3), 27-40.

Lebedev-Kumach, V. (1938). Velikiy pesennik shotladnskega naroda. Literaturnaya gazeta, 45, 5-15.

Morozov, M. (1947). Robert Burns. Introduction to Robert Burns in S. Marshak's Translations, Moscow: Gosizdat, iii -viii.

O'Dell, A. F. (1978). Socialization through Children's Literature: the Soviet Example. London: Cambridge University Press.

Rait-Kovaleva, R. (1959). Robert Berns o sebe. Novyi mir, 6,187-214.

Richmond S. and V. Solodin (1997). The Eye of the State: An Interview with Soviet Chief Censor Vladimir Solodin. Russian Review, 56, 4, 581-590.

Rogov, V. (1959). Певец свободы, Молодая гвардия, 1, 185-187.

Samarin, R. (1959). Роберт Бернс. Sovetskii soiuz, 2, 50-57.

Safiullina, N. (2012). The Canonization of Western Writers in the Soviet Union in the 1930s. The Modern Language Review 107, 2, 559-584.

Sherry, S. (2012). "Censorship in Translation in the Soviet Union in the Stalin and Khrushchev Eras". Doctoral dissertation, University of Edinburgh.

Sinitsyna, O. (1999). Censorship in the Soviet Union and Its Cultural and Professional Results for Arts and Art Libraries. Inspel, 33, 35-42.

Stelmakh, V. D. (2001). Reading in the Context of Censorship in the Soviet Union. Libraries and Culture 36, 143-150.

Witt, S. (2001). Between the Lines. Totalitarianism and Translation in the USSR. In: B. James Baer (ed.), Contexts, Subtexts and Pretexts: Literary Translation in Eastern Europe and Russia, Amsterdam \& Philadelphia: John Benjamins, 149-170.

Received: 21 May 2018

Accepted for publication: 28 December 2018 
Наталија Калох Вид

\section{УЛОГА ПАРАТЕКСТОВА У ПОСРЕДОВАҢУ ИДЕОЛОШКИ ПРИРЕЪЕНИХ ПРЕВОДА У СОВЈЕТСКОМ САВЕЗУ: СЛУЧАЈ РОБЕРТА БЕРНСА}

\section{Сажетак}

Главни циљ овога истраживања јесте да покаже како је комунистички режим успостављен у Совјетском Савезу после Октобарске револуције и оличен у централизованој државној контроли над свим друштвеним дискурсима, укључујући и књижевност, функционисао у пракси. Овај рад се бави приказима, предговорима и чланцима који су пратили совјетске преводе Роберта Бернса, једног од најпознатијих и највољенијих иностраних песника у Совјетском Савезу, њиховим утицајем на читаоце и значајем који су имали у пружању подршке званичној идеологији. Захваљујући томе што је совјетска штампа објављивала разноврсне материјале о Бернсу, тежиште овога чланка је на радовима који су се појавили у периоду између 1930. и 1950. године, када је званична слика Бернса први пут представљена. Паратекстуална средства која су власти користиле између 1930. и 1950. године да би промовисале идеолошки подесну слику Бернса укључују највише адаптације и чак фабрикације песникове биографије, и идеолошки подесна тумачења Бернсових песама. Улога манипулативних паратекстуалних средстава значајна је када се има у виду да су читаоци могли да упознају свет стране културе највише кроз књижевне преводе.

Кључне речи: паратекстови, идеологија, Роберт Бернс, совјетски, преводи 